\title{
Application of ARCUS digma I, II systems for full mouth reconstruction: a case report
}

\author{
Chan Park* \\ Department of Prosthodontics, School of Dentistry, Chonnam National University, Gwangju, Republic of Korea
}

Transferring condylar and anterior guidance on an articulator is essential to the diagnosis of a patient for full mouth reconstruction. In this clinical report, ARCUS digma I system was used to measure inherent condylar guidance of a patient requiring full mouth reconstruction in preoperate treatment, and the patients was given provisional restoration based on a functional anterior guidance. Then, ARCUS digma II system was used to mount the final casting model on an articulator, and the definitive prosthesis was placed in the patient. An esthetic and functionally proper clinical result regarding inherent condylar path of the patient was observed, and results from comparison of the two systems are given in this case. (J Dent Rehabil Appl Sci 2016;32(4):345-50)

Key words: ARCUS digma system; condylar guidance; anterior guidance; full mouth reconstruction

\section{Introduction}

Setting diagnostic cast in biological position with semi-adjustable articulator and reproducing mandibular movement are essential in patients requiring full mouth reconstruction. Transferring condylar guidance inherent to the patient is critical, and facebow transfer is also important to position the cast on the articulator properly. Pioneers in this field have used checkbite with wax to transfer patients' inherent guidances, but there are limitations with the method due to possible errors in the material used, in clinician's capability, and in linear movement of the articular complex regardless of actual morphology of the condylar fossa. To overcome such limitations, ARCUS digma system (KaVo Dental GmbH, Biberach, Germany) which records and analyses

*Correspondence to: Chan Park

Subspecialty Fellow, Department of Prosthodontics, School of Dentistry, Chonnam National University, 33 Yongbong-ro, Buk-gu, Gwangju, 61186, Republic of Korea Tel: +82-62-530-5638, Fax: +82-62-530-5639, E-mail: upgradepc@hanmail.net Received: July 18, 2016/Last Revision: August 9, 2016/Accepted: August 16, 2016 mandibular movement in three dimensions with ultrasonic electronic sensor to measure condylar guidance on a computer was developed recently. An upgraded model, ARCUS digma II have been released and is currently being distributed. Previous model, digma I, movement path is recorded and the mean value is used for average mounting, but digma II uses a receiver on facebow to set occlusal plane and a transmitter on buccal aspect of mandibular teeth to record three dimensional mandibular movements. Real-time reproduction of mandibular movement can be shown through a monitor, and condylar and anterior guidances can be identified. Also, evaluation of centric relation reproducibility and an accurate reproduction of mandibular movement on an articulator are possible with the system.

Copyright@ 2016 The Korean Academy of Stomatognathic Function and Occlusion. (c) It is identical to Creative Commons Non-Commercial License. 


\section{Case Report}

A 63-year-old Korean man visited Department of Prosthodontics at Chonnam National University, Gwangju, Korea, with chief complaints of overall attrition of teeth and discomfortness of old dentures. A detailed dental history revealed loss of multiple teeth and dental restoratives with fracture or improper margin, and thus his occlusal plane was out of an acceptable range (Fig. 1). Due to severe loss of alveolar bone on panoramic radiograph, mandibular anterior teeth were to be extracted, and the maxillary left canine and the first premolar required endodontic treatment with lesions. Preliminary impressions were taken, and inherent condylar guidance of the patient was determined with ARCUS digma I (Fig. 2A). Centric relation was recorded on a silicone bite, and same manufacturer articulator (Protar EVO 7, KaVo Dental $\mathrm{GmbH}$ ) was used for the mounting process in or- der to utilize the value recorded with ARUCS digma I (Fig. 2B, 2C). After analysis of centric relation, anterior teeth length, pronunciation, esthetics, $2 \mathrm{~mm}$ of vertical dimension increase was planned to give proper vertical dimension and ideal occlusal plane. A preoperative wax-up was made to improve improper anterior guidance caused by old prosthesis and to

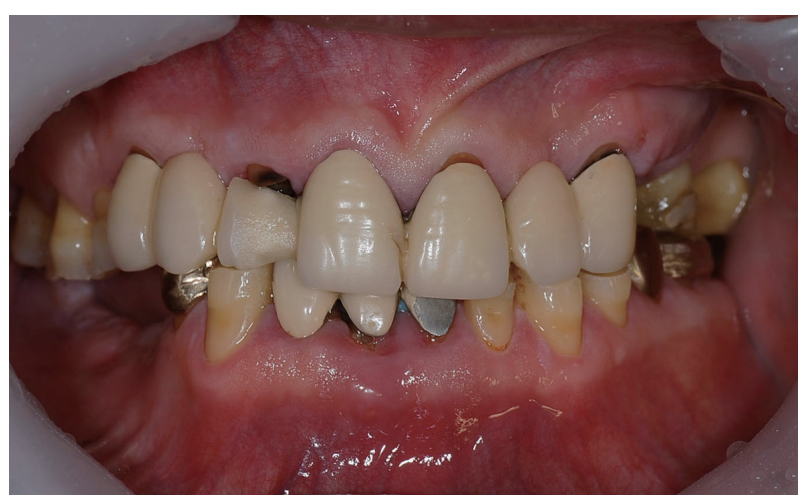

Fig. 1. Preoperative photograph: frontal view.

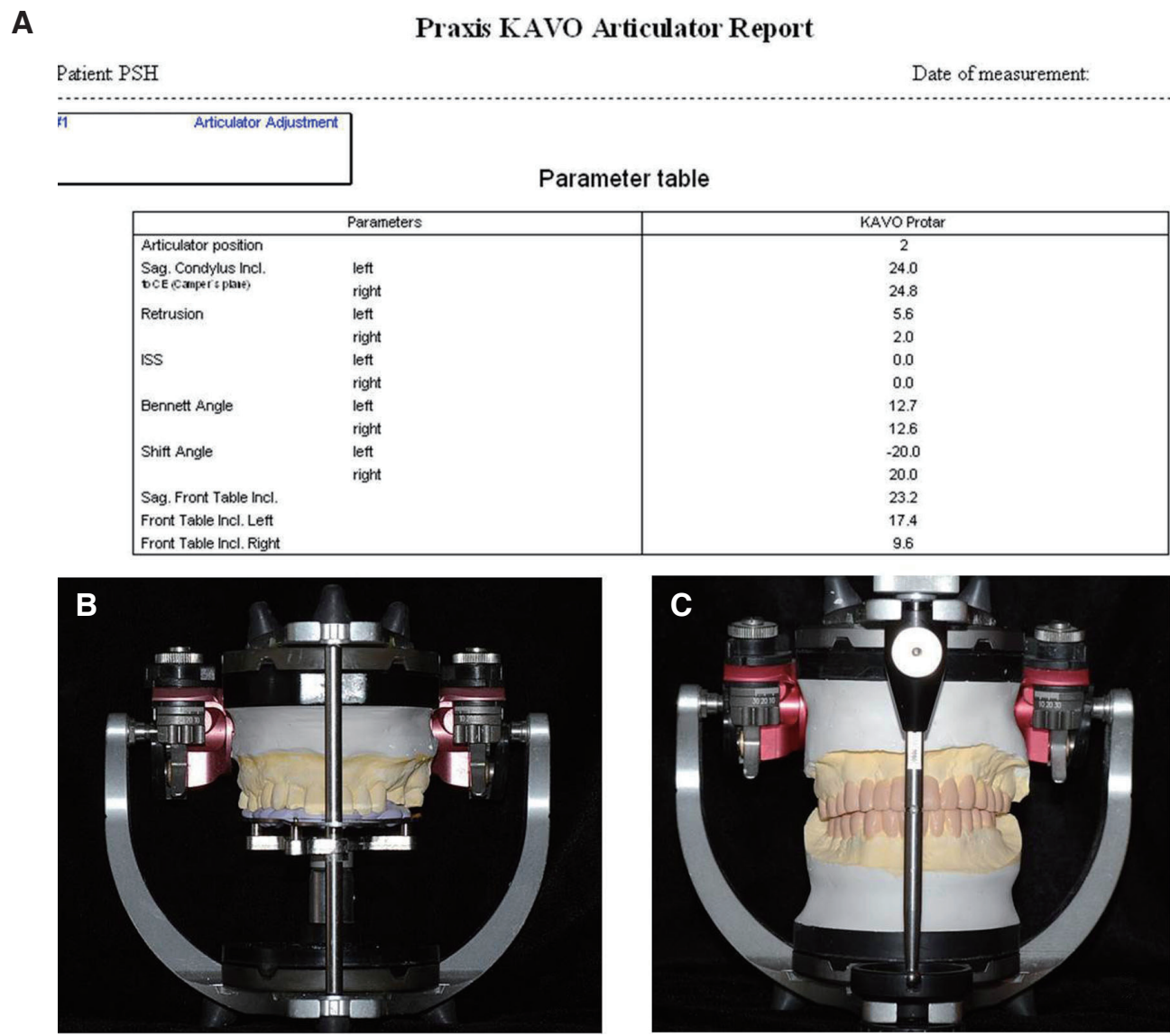

Fig. 2. Diagnostic procedure: (A) ARCUS digma I data (1st visit), (B) Average mounting by manufacturer recommended protocol, (C) Preoperative wax up. 
provide adequate posterior disclusion. Old prosthesis was removed, and endodontic treatments followed by direct post and core restoration were preceded on teeth with periapical lesions. Three dental implants were placed in the right mandibular second premolar, second molar, and left maxillary first premolar. Remaining teeth were prepared for restoration (Fig. 3), and they were filled with provisional restoration using a preoperative wax-up (Fig. 4). During 3 months, ARCUS digma I, II systems were used for evaluation occlusal adjustments to give a stable mandibular position, and finally the anterior guidance was set as the clinician planned. After the 2nd surgery for implant prosthesis, final impressions were taken, and the centric relation was recorded with provisional restoratives. The mounting was preceded with a new function in the ARCUS digma system II based on individual hinge axis (Fig. 5). Definitive prosthesis which mounted (Fig. 6) with the new data were set and adjusted by T-scan II (Tekscan Inc. South Boston, USA). After setting, it was possible to get the

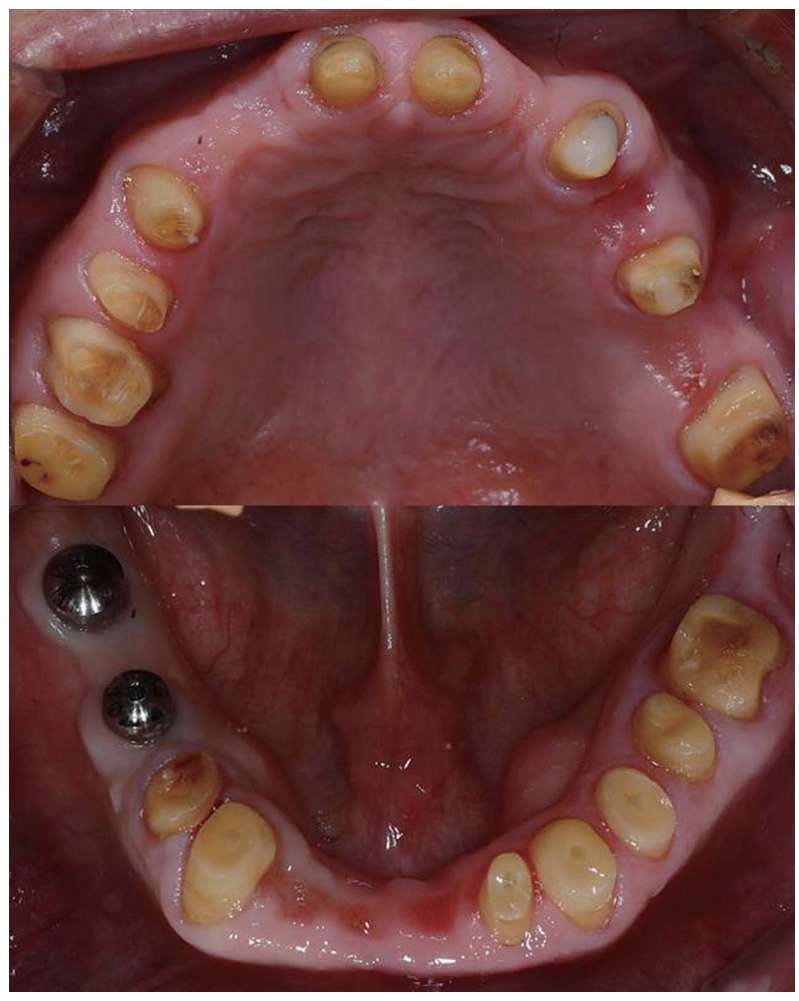

Fig. 3. Preparation photograph. accurate occlusion with the only minimal adjustment. The condylar guidance was checked with ARCUS digma II and was compared with that by ARCUS digma I at the first visit (Fig. 2A, 7). Electronic position analysis (EPA) test in ARCUS digma II was used to verify accordance of the centric relation with the maximal intercuspal position (Fig. 8).

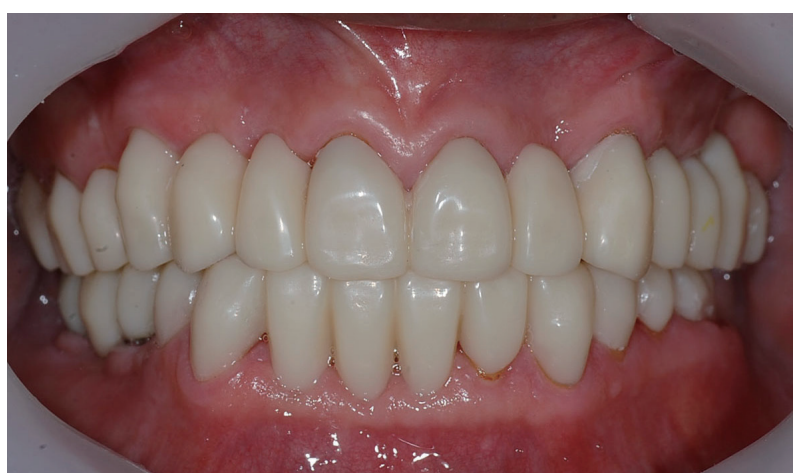

Fig. 4. Provisional restoration.

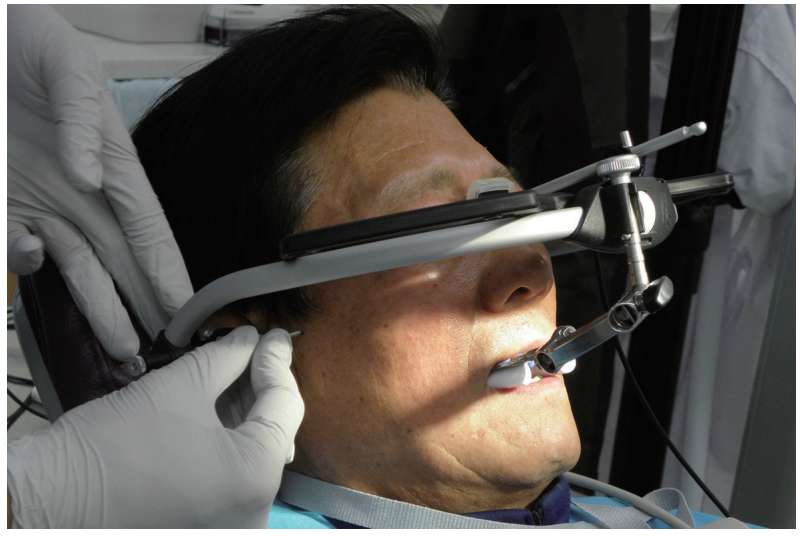

Fig. 5. ARCUS digma II facebow transfer \& individual hinge axis taking.

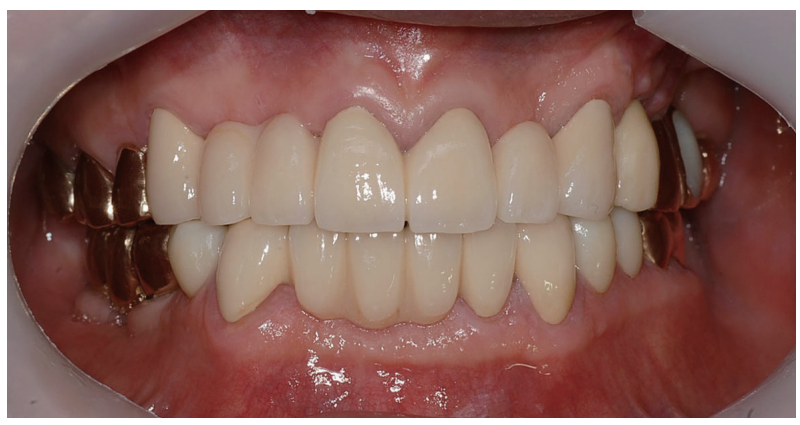

Fig. 6. Definitive restoration. 


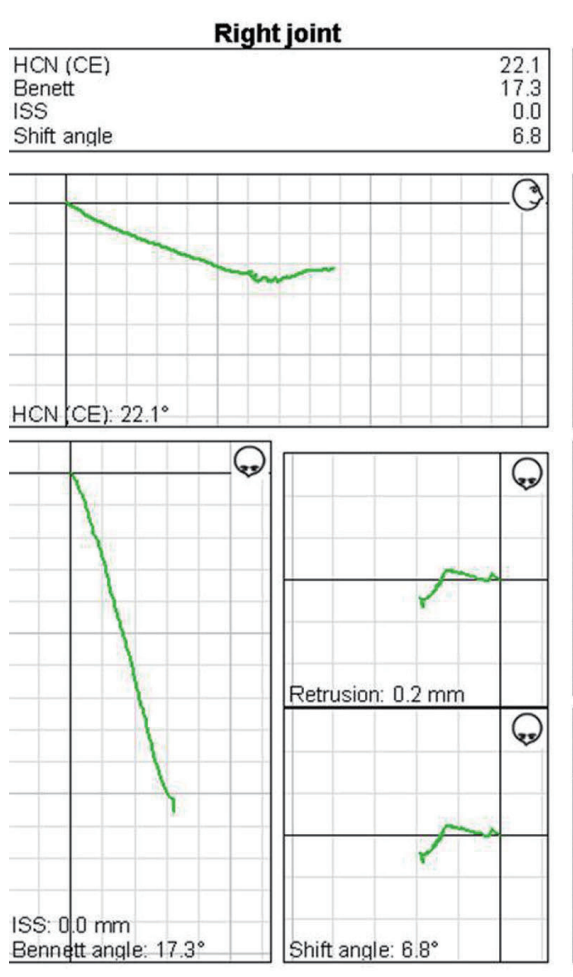

\begin{tabular}{|ll|}
\multicolumn{2}{c}{ Tooth guidance } \\
\hline Center (CE) & \\
Left & 28.9 \\
Right & 18.7 \\
\hline
\end{tabular}

\begin{tabular}{|lr|}
\multicolumn{1}{c}{ Left joint } \\
\hline HCN (CE) & 24.0 \\
Benett & 20.8 \\
ISS & 0.0 \\
Shift angle & -20.0 \\
\hline
\end{tabular}
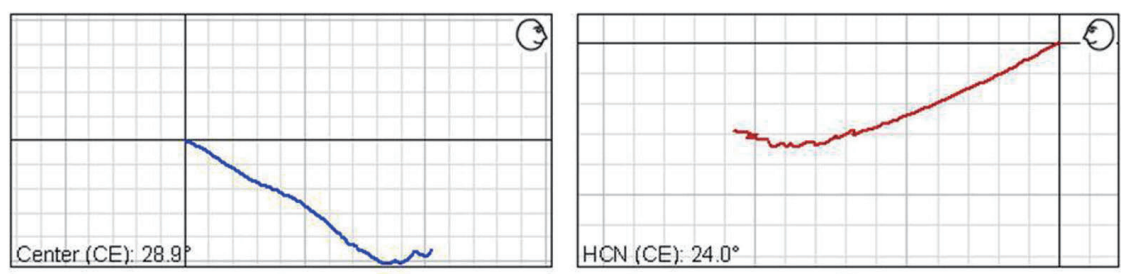

HCN (CE): $22.1^{\circ}$

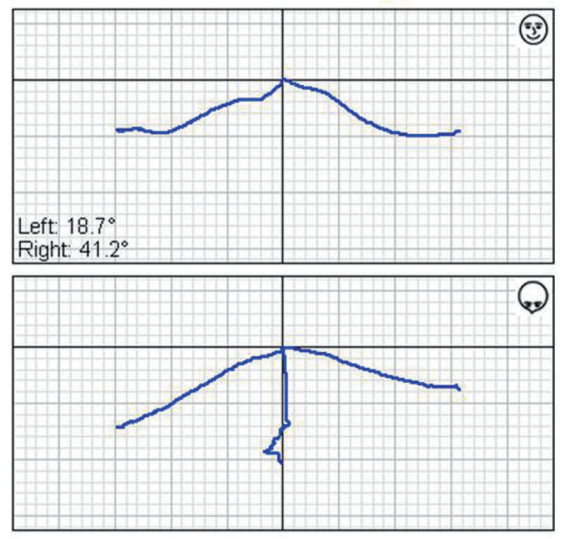

Fig. 7. ARCUS digma II data graph.
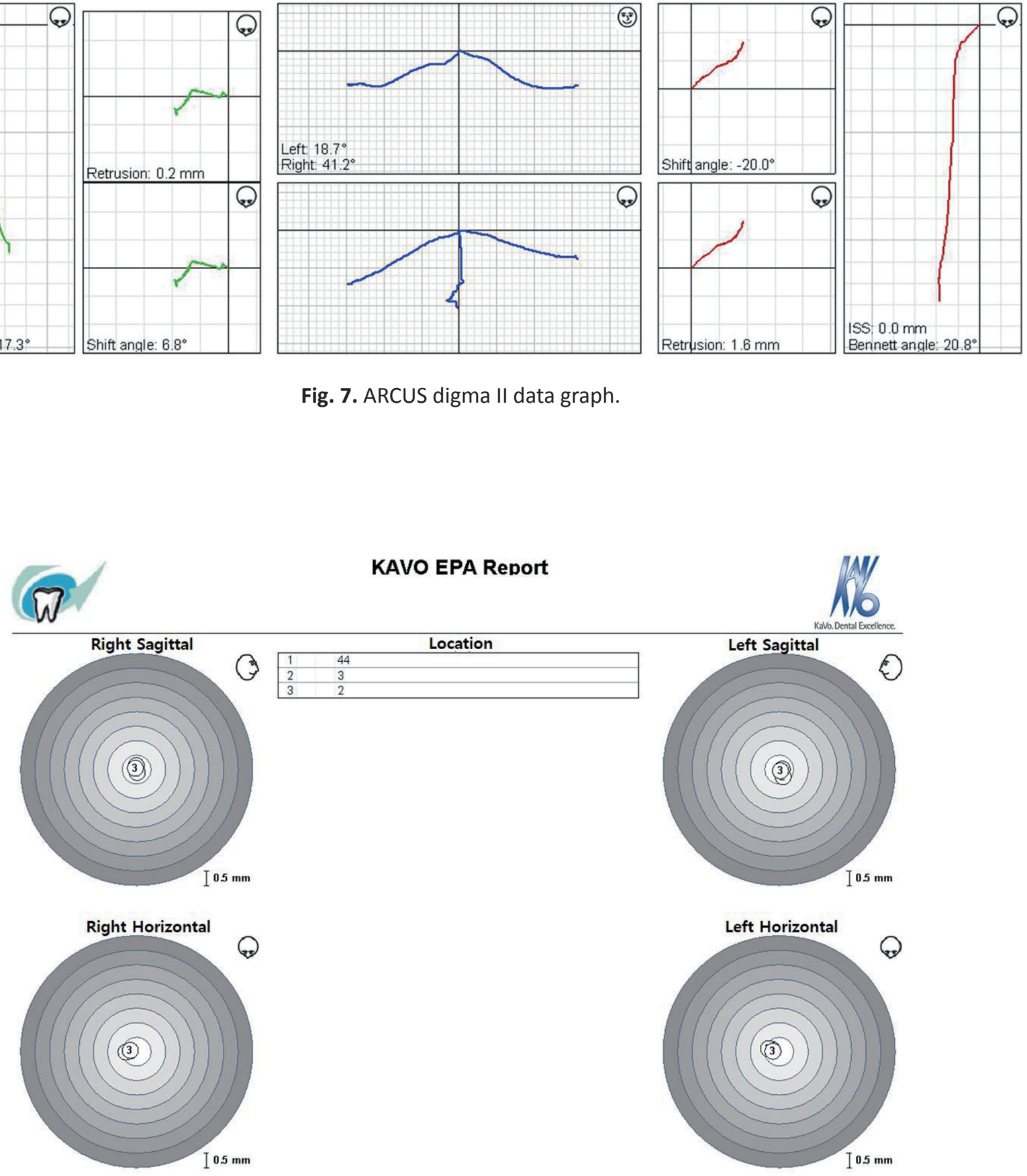

Fig. 8. ARCUS digma II EPA (electronic postion analysis) test. 


\section{Discussion}

In this case report, the inherent condylar guidance in a patient was acquired with ARCUS digma system, and it was applied on a same manufacture articulator to reproduce functional movement. Mullick et al. ${ }^{1}$ demonstrated that clinical results could be affected by the thickness of the material used when registering mandibular movement using checkbite and Adrien and Schouver ${ }^{2}$ have reported that maximum of $0.312 \mathrm{~mm}$ error can occur when the thickness of wax is $3 \mathrm{~mm}$. According to Craddock, ${ }^{3}$ in the study using checkbite, the results showed no consistency when wax was used to register mandibular movement. This report was used to ARCUS digma system for overcomes the limitation by using wax bite.

Number of studies have focused on condylar guidance with values based on Frankfort horizontal plane, Camper's plane, and other planes. ${ }^{4}$ Camper's plane was used in this clinical report, and el-Gheriani reported the right and left sagittal condylar guidance as $27.72^{\circ}$ and $26.54^{\circ},{ }^{5}$ respectively, not significantly different from this report. In this case, the method above was applied and to confirm its value, ARCUS digma I, II systems were also used. The value aquired by both above was not significantly different. Applying methods by previous scholars, validity in accuracy of ARCUS digma system was confirmed.

Values applied in this report were mean values of ARCUS system I or II data at first visit, at followup on provisional restoration, and after finial setting, taken three times each because the clinician made arbitrary decision as each value varied slightly. The first reason for such variance is that there is not concrete landmark to set facebow on camper's plane, and the second is that there exists slight difference in lateral and anterior limited movement even with the clinician's instructions.

ARCUS digma II, an upgraded model, has increased number of ultrasonic sensor and thus can measure condylar guidance quicker than ARCUS digma I system. However, the increased weight of the sensors pulled the facebow downward constantly, making the measurement slightly difficult. Also, not a significant difference was found in measured data compared to ARCUS digma I system, so more researches are needed to determine accuracy in measurements.

According to dos Santos et al., ${ }^{6}$ a pantograph is reported to be more accurate than a wax bite. ARCUS digma system will allow more accurate and faster processes for clinics and technicians using electronic sensor in condylar guidance measurement in a similar manner with the pantograph. However, there still are limitations in inconvenience, clinical error production, and lack of enough data. More researches are required in order to overcome such limitations to produce a new, reliable method.

\section{Conclusion}

ARCUS digma system was used to accurately reproduce inherent condylar guidance and locational relationship of maxilla and mandible in a patient requiring full mouth reconstruction, and the functional and esthetical results of the final prostheses were exceptionally satisfactory.

\section{ORCID}

Chan Park http://orcid.org/0000-0001-5729-5127

\section{References}

1. Mullick SC, Stackhouse JA Jr, Vincent GR. A study of interocclusal record materials. J Prosthet Dent 1981;46:304-7.

2. Adrien P, Schouver J. Methods for minimizing the errors in madibular model mounting on an articulator. J Oral Rehabil 1997;24:929-35.

3. Craddock FW. The accuracy and practical value records of condyle path inclination. J Am Dent Assoc 1949;38:697-710.

4. Olsson A, Posselt U. Relationship of various skull reference lines. J Prosthet Dent 1961;11:1045-9.

5. El-Gheriani AS, Winstanley RB. Graphic tracings of condylar paths and measurements of condylar angles. J Prosthet Dent 1989;61:77-87.

6. dos Santos J Jr, Nelson S, Nowlin T. Comparison of condylar guidance setting obtained from a wax record versus an extraoral tracing: a pilot study. J Prosthet Dent 2003;89:54-9. 


\section{ARCUS digma I, II system을 활용한 전악수복 증례}

\section{박 찬*}

전남대학교 치의학전문대학원 보철학교실

전악 재건이 필요한 환자의 진단 과정에서, 환자 고유의 하악 운동을 재현해 내기 위해 환자의 시상과로각과 전방 유도 각을 교합기 상에 인기하는 것은 필수적이다. 이번 증례에서는 전악 수복이 필요한 환자에게서 ARCUS digma I system 을 이용하여 환자 고유의 과로각 채득 후, 기능적으로 알맞은 전치 유도각을 설정하여 이를 바탕으로 교합 거상이 적용 된 임시치아로 적응하도록 하였다. 그 후 ARCUS digma II system을 활용하여 교합기상에 최종 마운팅하여 보철물을 장 착함으로써 심미적이면서도 환자의 고유 과로각에 알맞은 기능적 임상결과를 얻었을 뿐 아니라, 두 시스템간의 비교한 결과를 얻을 수 있었기에 이에 보고하고자 한다.

(구강회복응용과학지 2016;32(4):345-50)

주요어: 아커스 디그마 시스템; 시상과로각; 전방유도각; 전악재건술 